\title{
Teletandem and Performativity ${ }^{1}$
}

\section{Teletandem e performatividade}

\author{
João Antonio Telles* \\ Universidade Estadual Paulista \\ Assis - São Paulo / Brasil
}

\begin{abstract}
Teletandem is a virtual autonomous VoIP $\mathrm{I}^{2}$ technology-based context (webcam images, voice and text). Within this context, two students help each other learn their native (or other) language through intercultural and linguistic collaboration. Performative Theory can shed light on the constitution of these students' national identities, as they engage in linguistic performances of marking and discussing differences between their countries during teletandem. Based on critical approaches to discourse and intercultural communication, my analysis shows that this online intercultural contact opens innovative possibilities for foreign language teachers to promote intercultural contact with "the different". However, without teacher mediation, teletandem interactions may fall into shallow performances of sedimented and pre-given representations of self and other. Subsequently, this article concludes with a discussion of relevant pedagogical points for foreign language teachers.
\end{abstract}

KEYWORDS: teletandem; tandem; telecollaboration; performativity; foreign language.

RESUMO: Teletandem é um contexto virtual e autônomo que utiliza recursos de tecnologia VOIP (imagens de webcam, voz e texto). Neste contexto, dois estudantes de línguas estrangeiras colaboram um com o outro na aprendizam de sua respectivas línguas nativas (ou de proficiencia) por meio da interação intercultural e linguística. A Teoria da Performatividade pode esclarecer a constituição das identidades nacionais desses alunos quando eles marcam e discutem diferenças entre seus dois países durante sessões de teletandem. Com base em abordagens críticas ao discurso e a comunicação intercultural, minha análise mostra que o contato intercultural on-line abre possibilidades inovadoras para professores de línguas estrangeiras promoverem o contato intercultural com o "diferente". No entanto, sem a mediação do professor, as interaçôes de

\footnotetext{
*tellesjoao@uol.com.br

${ }^{1}$ This article is a partial result of the project Teachers' perspectives on the implementation of teletandem sessions into the foreign language curriculum, funded by FAPESP - Fundação de Amparo a Pesquisa do Estado de São Paulo (Proc. 2014/05910-8).
}

${ }^{2}$ VoIP - Voice-over-Internet Protocol. 
teletandem podem se restringir a performances superficiais e pré-determinadas de representações sedimentadas de si e do outro. Concluo com uma discussão acerca de pontos pedagógicos relevantes para professores de línguas estrangeiras. PALAVRAS-CHAVE: teletandem; tandem; telecolaboração; performatividade; língua estrangeira.

\section{Introduction}

Current technology has advanced and simplified the use of computerbased teleconferencing amongst peoples of different nations and languages, transcending geographic and national boundaries, thus making it accessible to people of diverse social levels and professions. Focus on the cultural dimension of this online webcam communication is necessary in order to fully understand the intercultural discourse that underlies this type of interaction (TELLES \& FERREIRA, 2011). In turn, deepening our understandings of the discourses in these virtual intercultural contacts seems to be important for strategic, political, pedagogical, and educational reasons, among others. Moreover, we have been increasingly dealing with it in our daily lives when interacting with others through the internet, tablets, smartphones, and even the most updated telepresence and hologram technologies ${ }^{3}$.

Teletandem is a virtual, autonomous, and collaborative context that uses online teleconferencing tools (text, voice, and webcam images of VoIP technology, such as Skype) to promote intercontinental and intercultural interactions between students who are learning a foreign language. During teletandem sessions, two foreign language students collaborate online to help the partner learn each other's native language (or language of proficiency) by following principles of foreign language learning in tandem (BRAMMERTS, 2003).

Performative Theory (BUTLER, 1999), in turn, can shed light on the constitution of subjectivities of foreign language students who use this kind of situated online webcam based interaction - teletandem. Although Butler's work focuses on gender identity and categories that are constituted in discursive practices, her Performative Theory can help us to obtain a perspective of teletandem student interactions as performatively constituting national identities, such as being Brazilian or being American.

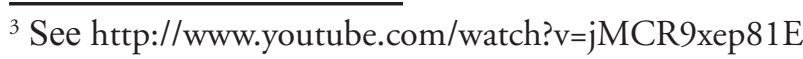


This paper therefore adopts the perspectives of Performativity Theory in the analysis of a teletandem interaction between two university students (one Brazilian and one American). This analysis foregrounds one aspect of teletandem interaction activities over others. More specifically, this study seeks to analyze the ways through which the Brazilian partner performs her notions of "Brazil", of "Brazilians" and of "what Brazilians do" as she interacts with her American partner.

Therefore, this paper has two objectives: (a) to argue for the fact that Performative Theory can shed light on the constitution of national identiies of foreign language students as they engage in linguistic performances of marking and discussing differences between their countries during a special collaborative and autonomous mode of teleconferencing - teletandem; and (b) to reflect on pedagogical implications upon foreign language pedagogy after analyzing excerpts of one video-recorded teletandem interaction from the perspective of Performativity Theory.

The two research questions adopted here were: (1) How do teletandem practitioners perform their national identities during the intercultural interaction of teletandem? (2) What enhancements can foreign language pedagogy have once online interactions in teletandem are considered from the perspective of performativity?

The first section of this paper outlines the theoretical framework of this study, which focuses on teletandem and performativity theory, as well as on approaches to culture and intercultural communication. The second section describes the methodology of the study and presents a Critical Approach to Discourse and Intercultural Communication (KUBOTA, 2012; CANAGARAJAH, 2012) - a methodologically complementing perspective through which to examine the data, the participants, the context of the study, the instruments for data collection and analysis, and the procedures for analyzing the data. The third section presents the results of this analysis. This paper concludes with a discussion on the underpinnings of using teletandem in the foreign language curriculum and with a few reflections on foreign language teacher roles for this purpose.

\section{Theoretical Framework}

\subsection{Teletandem}

The tandem principles of autonomy, reciprocity, and no mixture of the two languages were adapted to a virtual environment mediated by text, voice, 
image, and message software, such as Skype, Windows Live Messenger, and OoVoo, among others. which was given the name of teletandem, as previously defined by TELLES \& VASSALO, 2006, 2009; VASSALO \& TELLES, 2008; and TELLES, 2009a. Subsequent research (SANTOS, 2008, 2009; BROCCO, 2009; LEONE, 2009) has shown that online teletandem interactions commonly include a wide range of language-related episodes, in which students stop the flow of conversation events to focus on the use of language, lexicon, and/or on meaning negotiation (SWAIN \& LAPKIN, 1998). However, the intercultural dimension of teletandem interactions has not been sufficiently explored, with a few exceptions, as can be seen in MENDES, 2009; BENEDETTI, 2010; BENEDETTI et.al, 2010; and SALOMÃO, 2011a, 2011b, as well as at introductory levels in MOITEIRO, 2009; RODRIGUES, 2008; and GÓIS, 2009.

This paper departs from three characteristics that have been quite frequent and prominent in teletandem conversations between foreign language students through Skype, which is the case of this project:

a) teletandem conversation sessions are frequently and essentially focused on contrasting the daily lives in each of the partners' countries, with emphasis on themes of interest to the partners, on vocabulary meaning negotiation, as well as on grammar input or discussion about grammar rules (SANTOS, 2008, 2009; BROCCO, 2009);

b) the content discussed during these interactions is basically grounded on marking differences between the partners' countries (BENEDETTI et al., 2010; TELLES \& VASSALO, 2006); and

c) discussions on these differences are frequently repetitive, involve common sense, and are essentialist in nature - cultural ascriptions (PENNYCOOK, 2012, p. 526). In line with Piller's thoughts, the discussions deal with "the twin problems of essentialism ("people have a culture") and reification of national and ethnic identity as culture ("people from group $\mathrm{X}$ behave in ways that are static, internally similar and different from other groups")" (PILLER, 2012, p. 6-7).

Despite the positive points of online intercultural interactions in teletandem (see TELLES \& VASSALO, 2006), the three characteristics above (particularly "c") can be seen as problematic to a foreign language education curriculum that aims to promote students' intercultural communication and 
intercultural citizenship. To broaden students' worldviews and to promote deeper and critical understandings and appreciation of the differences, the essentialisms of these online conversations can first be accessed through critical approaches to intercultural discourse and communication (KUBOTA, 2012; CANAGARAJAH, 2012). Thus, these essentialisms must be deconstructed and the matrix of their organization revealed for critical scrutiny. The results can then inform teacher development programs so that future foreign language teachers can deal with the shortcomings of teleconference interactions between students of foreign languages. As a result, new pedagogical and curricular possibilities can be obtained from these interactions. If not appropriately mediated by the foreign language teacher, the virtual, autonomous, and collaborative context of teletandem may backfire into a series of cultural essentialisms and prevent students' dynamic and diverse understandings of culture. Therefore, the teachers' role is quite important in and necessary to the implementation process of teletandem in the foreign language curriculum (see TELLES, 2009b and SALOMÃO, 2011a).

\subsection{Performativity theory and teletandem}

Teletandem discourse is basically characterized by performances of differences. This is to say that, in the online intercultural contact (see KRAMSCH \& URYU, 2014) through teletandem sessions, partners constantly and discursively "mark differences." In the case of this study, students perform this by implicitly or explicitly contrasting views of Brazilians, of Brazil, and of what Brazilians do with those of Americans, of the United States, and of what Americans do. An example of an explicit marking of difference would be the phrase: "In Brazil, girls dress more sensually than do the girls in the US." An example of an implicit marking of difference would be: "Brazil still has a lot to accomplish in terms of literacy," meaning "in comparison to one's or another's country." Partners can also mark differences in relation to a third party country, for example: "People of X country are piggish" (see Excerpt 1, below).

Marking these differences thus impacts the constitution of identities, as shown by Woodward (2000, p.9-14). How? For this author, among other characteristics, identity is mainly: (a) fabricated (imagined) by symbolic differences - some more important than others and usually expressed through verbal or non-verbal discourse (a language, an accent, a flag, an earring, a 
brand of cigarette one smokes); (b) relational, that is, it depends on some external factor in order to exist (another identity that supplies the conditions for it to exist); (c) sustained by exclusion (if you are Brazilian, you cannot be American); (d) linked to social and material conditions. Most commonly, these differences are sedimented in the learners' social contexts through the repetition of social practices and classificatory/regulatory frames.

The intercultural contact through teletandem provides students with opportunities to notice and to express these differences. Technically, this online context is characterized by the use of text, voice, and one's own webcam image, contemporaneously with that of his/her partner, such as on Skype. Such characteristics make this kind of interaction different from other conventional, natural, face-to-face conversations. In face-to-face conversation, we are unable to have an idea of "how we look", except from that which our interlocutors present to us. In teletandem conversations, because we can also see ourselves through a webcam image, we gain control not only of our own looks, but also of our reactions that are conveyed to our partner (see TELLES, 2009c, 2012). Since, according to Kulich (2003, p.140), "performativity is the process through which the subject emerges," we can consider the foreign language interaction in teletandem as also dynamically constituting (rather than representing) their participants' realities. This happens during the discursive practices of teletandem sessions, as the two participants try to explain their cultures and languages to each other, and as they gain more control over their personal image. One's own webcam image is a discursive construction. Such a construction is built upon the performativity process that draws on the repetition and iteration of codes and symbols, such as gestures, hairstyle, clothes, earrings, make-up, and flags (BUTLER, 1990). All of these will help to produce the emergence of gender, race and national identification, sexual orientation, social class, and, most importantly, the subject.

According to Kubota (2012, p. 95-96):

“(...) performativity suggests that cultural and linguistic expressions, just like expressions of gender identities, are performed by members of a community, rather than simply being dominated or controlled by external objective mechanisms called language and culture. (...) what structures social practice and perspective is not a preexisting system of culture or language but people's acting on symbols and not only iterating actions, but also appropriating, resisting, bending, and inventing language and culture." 
Previously, Miller (2012) and McIlvenny (2002) also reflected on performativity and foreign language learning. Their studies concluded that learners' common sense understandings of perceived realities of language and of the native speaker are performatively constituted through ESL classroom interactions (Miller, 2012, p.89).

This paper seeks to defend that teletandem partners contrastively perform these views as taken-for-granted realities. As Miller (2012) argues, and I agree, it can be construed (as illustrated further below) that teletandem partners performatively constitute these taken-for-granted social realities as they try to explain their lives and culture. Miller also states: "such performances do not constitute social reality in a historical vacuum" (p.3). Moreover, such performances, in my opinion, are not free of social markers of difference (gender, race, ethnic, schooling, and social background, to mention only a few). Accordingly, the cultural views presented by teletandem practitioners are "re-sedimented conventions of earlier iterations of discursive practices" (p. 3), and these may serve "as occasions for reconstituting social ideologies" (p. 3) (in this case, about Brazil/US and about Brazilian and American subjectivities). If that is possible, teletandem and its idea of promoting transcultural contact and dialog with peoples from other parts of the world may in fact serve as a virtual context for performativity.

Drawing insights from studies about Performative Theory, this paper defends that foreign language students' ideologies about language as autonomous and homogeneous systems, about national identities, as well as about social lives in different countries, are performatively produced and not merely represented in their (intercultural) discursive practices of teletandem interaction. Like in Kramsch \& Uryu (2014), this paper also considers the online interacultural contact through teletandem as "a site of struggle in which we are as much the active producers of discourse as we are the speakers of discourses beyond our control" (p.219).

Constructing differences is an exclusionary process. As Vasterling (1999; also cited in MILLER, 2012, p. 10) explains: "exclusion and production are two sides of the same coin". When Brazilians talk about their own country, about themselves, and about what they do with an American teletandem partner, they end up, implicitly, performing their views of the United States, about Americans, and about what Americans do. The key point is: how are such constructions treated in the intercultural discourse of online teletandem practices? 


\subsection{The cultural dimension of teletandem interactions}

This study concerns how communication takes place across cultures through the online intercultural contact promoted by teletandem. Therefore, it is necessary to examine how culture is conceptualized here. First, the objective is to avoid relying on a static and essentialist understanding of culture by adopting a poststructuralist view: “(...) culture knowledge, or the ways we understand and describe a certain culture, is constructed by discourse - a meaning/subjectivity-making system mediated by language, signs, and other modes of communication (...)" (SHI, 2001, p. 282; also cited in KUBOTA, 2012, p. 95-96). Such an understanding of culture allows me to inspect a performative dimension of culture and language (as we will see in the analysis of the transcriptions below). Such an understanding of culture also runs in line with Butler's (1990) notion of performativity.

Levy (2007) presents five facets of the culture concept that provide a focus to think about culture. These five facets can be easily recognized in the transcripts and analysis of this paper's teletandem interactions, as students perform their Brazilian and American identities ${ }^{4}$. Synthetically, these cultural facets and their characteristics are: (a) culture as elemental (beginning from birth, people are deeply embedded in their own cultures and frames of reference); (b) culture as relative (one culture understood constrastively in terms of another; generalizations); (c) culture as group membership (people's beliefs and practices that identify and regulate membership with one specific group and differ them from other groups); (d) culture as contested (feelings of disquiet and uncertainty when core beliefs and values are challenged, reoriented, or reset - a clash of cultures and culture shock); and (e) culture as individual (variable and multiple - subjective and personal interpretation of a culture; perspectives of one's own culture vary from individual to individual) (LEVY, 2007, p. 112).

These studies on culture, culture learning, intercultural communication, and performativity help us understand people's strong tendency toward relying on common sense, as they mark differences during interactions with people from different countries, cultures, and languages (such as in teletandem). Marking differences plays a relatively important (if not crucial) role in people's processes of subjectivation, as

\footnotetext{
${ }^{4}$ The concept of performing identities was initially presented by Butler (1996) and used by Pennycook (2004, p. 13).
} 
shown by Woodward (2002) and Levy (2007). However, Guest (2002) points out the danger of these contrasts when dealing with cultures and teaching languages. The author claims that constrasting cultures reinforces stereotypes; constructs cultures as monolithic, static, stigmatizing, and exotic "Others"; and fossilizes stereotypes (p. 154-156). He suggests that since most interactions happen at the individual or small group levels, "culture should be seen as an interplay between social and personal schemas (...) and not national or racial cultures en masse" (p. 157).

\section{Methodology}

\subsection{Institution}

The study was conducted through a collaboration of two higher education institutions. One institution is located in the United States and is a high level private university ranked among the best in the United States in the area of Humanities. The other is a state funded and multi-campus university in Brazil, with one of the highest rankings within Brazilian and Latin American universities.

\subsection{Data collection procedures}

Seven teletandem sessions, through Skype, were video/audio recorded over a seven-week period (one session of one hour per week), between October and November 2010. Each teletandem session lasted approximately 60 minutes (30 minutes of English and 30 minutes of Portuguese). The software Screen Recorder for Macintosh was used to videotape the sessions. The recordings were then transferred to NVivo 10, a qualitative analysis software, and transcribed verbatim. The data considered in this paper is part of a larger bilingual corpus, composed of approximately 300 hours of recorded teletandem sessions between both universities and with the participation of approximately 100 students.

For the analysis conducted in this paper, only the parts of the session that were conducted in Portuguese were considered. I transcribed the original video-recorded interactions, and the subsequent translation was done collaboratively with a native speaker of English. In the data translation process, we tried to account for possible losses of meaning and for the importance of lexical and semantic choices of a study about the constitution 
of identities such as this one. The original excerpts in Portuguese could not be added to this paper due to restrictions of space.

\subsection{Participant profiles}

The excerpts analyzed below were taken from 3 of the 7 sessions carried out by an intercontinental teletandem partnership between a male American student (Daniel) in the United States and a female Brazilian student (Leticia) in Brazil. Both were university undergraduate students. Daniel was 19 years old, in his third year of International Relations, and had taken two previous semesters of Portuguese. Originally, he had come from a Caribbean country, had lived in the United States for 13 years, and spoke fluent Spanish and English. His objectives in teletandem sessions were to improve his oral skills in Portuguese and to learn about Brazil and Brazilians. The Brazilian female participant was 20 years old, born in Brazil; her native language was Portuguese, and she was in her first year of an undergraduate course in Modern Languages (Letras), with a double major in Portuguese and English. Her aims during the teletandem sessions were to improve her oral skills in English, a language she had studied for eight years, and to learn about the United States.

\section{Data analysis}

Based on Pennycook (2004), through the selection and analysis of the six excerpts, below, I tried to obtain evidence to support the idea that this supposed Brazilianness is discursively fabricated in the ongoing (in the doing of) linguistic performances of teletandem interaction, rather than being pre-given (p.1).

It is important to be reminded that, although only the transcriptions of what the students say are present below, when interacting through Skype, the students saw both their partner's image as well as their own on the computer screen. As they interacted, their gazes swap from one image to another (see also TELLES, 2009).

Excerpt 1 was taken from the very first teletandem interaction, when the partners, Leticia (Brazilian) and Daniel (American) introduced themselves to each other. 


\begin{tabular}{|c|c|}
\hline & $\begin{array}{l}\text { EXCERPT 1, Session 1: "Look! Brazilians are a little } \\
\text { LETICIA: OK. And what course are you enrolled in there? }\end{array}$ \\
\hline & DANIEL: I am studying international relations. \\
\hline & LETICIA: Cool. \\
\hline & $\begin{array}{l}\text { DANIEL: I am in the first four years of the course, / LETICIA: Hum./ DANIEL: Here in } \\
\text { the university, I study Latin America. So... I take... courses in Economics, Political Science, } \\
\text { languages./ LETICIA: Uh-huh. DANIEL: I am only studying Portuguese. But... I was born } \\
\text { in Cuba. So, I speak Spanish. }\end{array}$ \\
\hline 5 & LETICIA: Cool. \\
\hline & $\begin{array}{l}\text { DANIEL: I have... I have lived in the United States for } 13 \text { years, so I speak English. But, I } \\
\text { really like Portuguese! }\end{array}$ \\
\hline 7 & LETICIA: Oh, nice! (smiles)... And you... What year are you in? \\
\hline & DANIEL: Third year. \\
\hline & LETICIA: Third year? Oh... \\
\hline 10 & DANIEL: Hum..., so I still have two more... \\
\hline 11 & LETICIA: Oh... \\
\hline 12 & DANIEL: Hum... But, I like my course, and I think this is a good $u$ \\
\hline 13 & LETICIA: Sure! \\
\hline & DANIEL: Hum... And you? What do you do? \\
\hline & $\begin{array}{l}\text { LETICIA: I am... Here, I study Letras. In English that would be equivalent to Linguistics, } \\
\text { right? }\end{array}$ \\
\hline & DANIEL: Linguistics... \\
\hline & $\begin{array}{l}\text { LETICIA: Yes. And... I am studying English, you know... Only to get a diploma, because, } \\
\text { actually, I am fluent in the language, you know... Only to get the diploma. And... I like, } \\
\text { I am enjoying the course too, but... Really, I... Here in Brazil I took the college entrance } \\
\text { examination, you know, we have to take it to get into college. I took the examination to } \\
\text { enter the International Relations course. I took it twice, but it is, it is difficult and I could } \\
\text { not pass it. So, then, I started Letras and so... here I am here, I think it's cool, huh... this } \\
\text { interaction with someone who is taking International Relations. }\end{array}$ \\
\hline 18 & $\begin{array}{l}\text { DANIEL: Ok. And why do you say "tirar um diploma" [getting a diploma]? This means } \\
\text { what? Huh... }\end{array}$ \\
\hline 19 & $\begin{array}{l}\text { LETICIA: Oh... It would be as if, in English, as if I meant that I want... I want to have a } \\
\text { degree in English, understand? }\end{array}$ \\
\hline & DANIEL: So, this expression. "tirar um diploma" [get a diploma] is OK? \\
\hline 2 & LETICIA: Get a diploma, right. \\
\hline & $\begin{array}{l}\text { DANIEL: So, "eu quero tirar um diploma em Relações Internacionais" [I want to get a } \\
\text { diploma in International Relations]. }\end{array}$ \\
\hline & LETICIA: Right (smiles). That's how you say that. \\
\hline
\end{tabular}


Pennycook (2012, p. 539) argues for an understanding of performativity that allows us to view the production of identity in the doing. Excerpt 1 above gives us two examples of this doing: Daniel's performance of his identity as a student of International Relations (but not only that, as we will see), and Leticia's performance of her identities as a student and citizen of Brazil.

As Daniel and Leticia introduce themselves in their first online teletandem encounter, they perform their identities with words. The result of this performance reveals a process of marking each other's differences as students and in terms of choices of university courses and careers (line 4 for Daniel and line 17 for Leticia). Performativity occurs through their use of language (in this case, Portuguese, a foreign language for Daniel) to mark these differences and to show both partners' choices of pre-existing social and cultural practices of choosing a university course and career. Daniel's identity is performed as the Latin male who immigrated to the US from a Caribbean country and who entered a top level American university to take a course of his choice (International Relations). In turn, Leticia performs her identity as the Latin American female who applied twice for the same course (International Relations), but found it too difficult to pass. She therefore had no choice but to take the examination for a Linguistics (Letras) course, with a major in English as a Foreign Language, "only to get a diploma" because she is "already fluent in the language", thus meeting no challenges with no need for extra effort (line 17). She presents the constantly repeated and previously sedimented idea (at least in Brazil) that a Language Arts course is easy and does not present challenges.

Finally, as he introduces himself, it is clear that Daniel performs an identity of a student who focuses his career choices through his Latin roots. One can sense his effort to understand and to be close to such roots, as he emigrated from a Caribbean country when he was six and has been living in the United States for thirteen years (later, he says he is nineteen years old). Daniel says that he is fluent in English and Spanish, that he is studying a third language and that his studies focus on Latin America. These facts settle the context for his building of taken-for-granted connections between languages and countries.

However, these connections seem neither convincing nor very consistent. For example, he says: "I was born in Cuba. So, I speak Spanish" (Line 4). There is the possibility that he could not in fact speak Spanish, even 
though he was born in Cuba. Or when he says: "I have lived in the United States for 13 years, so I speak English" (Line 6). This may not be true, since there are many people who live in a foreign country without speaking the country's language. Finally, one wonders if he preferred to speak another Latin language instead of English. What other discursive effects could the use of "but" have meant in his utterance: "I have lived in the United States for 13 years, so I speak English. But, I really like Portuguese!” (Line 6)? Daniel's use of "but" may well have been a way of creating more proximity or even showing friendliness in his first online meeting with his Brazilian partner.

Excerpt 2 is also taken from the partners' first teletandem interaction, when the conversation turned to Leticia's experience of living in a foreign country, located on a different continent, for one year (below, I refer to this country as X and to the people of this country as X people). It is a particularly curious excerpt, because there is a shift of focus from the partners' cultures to a third culture (the X culture).

\begin{tabular}{|c|c|}
\hline 1 & $\begin{array}{l}\text { EXCERPT 2, Session 1: "X people are a bit piggish" } \\
\text { DANIEL: Yes, yes, yes. And, huh... did you like X [the country where Leticia has } \\
\text { been]? }\end{array}$ \\
\hline 2 & $\begin{array}{l}\text { LETICIA: You see [both laugh]... It depends. The... was interesting... The } \\
\text { experience, many things, you know, are different from here, you see, from Brazil, } \\
\text { many different things from [my continent]. It is REALLY different. But, I did } \\
\text { not like the... the... the dirt... X people are a bit piggish, have you noticed that? }\end{array}$ \\
\hline 3 & DANIEL: Sujeira [dirt]? What does sujeira mean? \\
\hline 4 & $\begin{array}{l}\text { LETICIA: All right. Sujeira [dirt] is, look, wait! [probably checks an online } \\
\text { dictionary] }\end{array}$ \\
\hline 5 & DANIEL: Sujeira... dirty. Oh! It's, it’s... Sucio in Spanish, sucio. \\
\hline 6 & LETICIA: That's it. \\
\hline 7 & DANIEL: [surprised voice] Do you know what sucio means in Spanish?! \\
\hline 8 & LETICIA: I know, I know. That’s exactly it. That’s it. \\
\hline 9 & DANIEL: That's it. So X is mui sucio [very dirty]. \\
\hline 10 & LETICIA: Very (laughs). \\
\hline 11 & DANIEL: Are you sure this is what you mean? \\
\hline 12 & $\begin{array}{l}\text { LETICIA: That's what I mean. They are... it's too polluted. They make things dirty, } \\
\text { they mess up the floor. They don't care much about cleanness. (Pause). You get it? }\end{array}$ \\
\hline
\end{tabular}

Leticia explains to her American partner her experience in the X country, with the $\mathrm{X}$ people, and with what $\mathrm{X}$ people do. As a recurrent characteristic of the intercultural discourse of teletandem sessions, there is a marking of difference and hence the marking of Leticia's Brazilian identity. 
She speaks with her American partner as a Brazilian. According to Woodward (2000, p. 9), "identity is marked by symbols" - cleanness, in the case of the above dialog. I would add that identity is also marked by what one does ("X people mess up the floor," as Leticia presents the X people to her American partner). Woodward (2000) argues that identity is relational and that it depends on another identity that gives the former the adequate conditions for the latter to exist. Furthermore, the author states that "difference is sustained by exclusion" (p. 9), in other words, if you are Brazilian, you cannot be X people, and vice versa; if you're dirty, you cannot be clean, and vice-versa. Thus, the effect of Leticia's marking of the difference between Brazilians (and, implicitly, Americans, in this case) and the X people suggests an individual, collective, generalized (Brazilian) identity, including an alleged superiority and advantage over the people of the X country - she and the Brazilians are clean, they do not mess up the floor and care for cleanness. This aspect (cleanness) of their individual and collective identity is sustained due to the contrast with the $\mathrm{X}$ people.

Interesting, though, is the way Leticia categorizes what she perceives as differences between Brazil and the X country. She did not even think about her American partner's reaction to what she says. Probably, since she is aware that her partner is not an X person or an X descendant, she feels "relatively safe" to express her sedimented view of both the X people and the $\mathrm{X}$ culture. She does not even seem to care about the possibility of her American partner having an X relative or even being an X descendant, given the existing multiculturalism in the United States.

Finally, there appears to be a certain constraint on the part of her American partner, who gradually becomes aware of the meaning of "dirt" (lines 3 and 5) and, twice, checks if Leticia really means what she is trying to say about X people (line 7: "Do you know what sucio means in Spanish?" and line 11: "Are you sure this is what you mean?"). Leticia confirms both times (line 8: "I know, I know. That's exactly it. That's it." and line 12: "That's what I mean.").

Excerpt 3 was also taken from the very first teletandem interaction, when partners were still introducing themselves to each other. It shows an American student trying to give his Brazilian partner a quite positive view of Brazil and a Brazilian student who is quite critical of her own country. 


\begin{tabular}{|c|c|}
\hline & $\begin{array}{l}\text { EXCERPT 3, Session 1: "Look! Brazilians are a little ungrateful." } \\
\text { DANIEL: So I ... I really like Brazil. I think Brazil is now co ... in a very crucial } \\
\text { moment of its history. }\end{array}$ \\
\hline 2 & LETICIA: Yeah, sure. \\
\hline 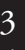 & DANIEL: It is at a moment of transition. \\
\hline 4 & LETICIA: Uh-huh... \\
\hline 5 & A: It has not only a regional, but a global potential as well. \\
\hline & B: Sure. \\
\hline & $\begin{array}{l}\text { A: And... And the projections of Brazil's power in the world are... are very } \\
\text { interesting. A very powerful emerging power. And I don't know what Brazilians } \\
\text { say about it, I do not know what Brazilians think about that, but, uh... That is the } \\
\text { perception outside of Brazil. I do not know what the perception within Brazil is. } \\
\text { What do you think? }\end{array}$ \\
\hline & $\begin{array}{l}\text { LETICIA: Look! Brazilians are a little ungrateful. We know that the country is } \\
\text { growing, is emerging okay, especially after Lula's government, you must know him. } \\
\text { It's... Brazil has had a very large international prominence after his government, } \\
\text { so, Lula is a celebrity outside of Brazil. And... Here, the country's intellectuals, } \\
\text { university scholars, people who have gone to school, people who are economically } \\
\text { and politically well informed, here in Brazil, they all agree that Brazil is an upcoming } \\
\text { power, a promising power. But most of the masses here... Brazil still has a lot to } \\
\text { accomplish in terms of literacy, I mean, people are not very interested in culture, } \\
\text { in the Arts, in politics, there are few people who are interested, so... But those who } \\
\text { are interested agree with your point of view, the masses here are a little ungrateful. }\end{array}$ \\
\hline & $\begin{array}{l}\text { DANIEL: Yes, I think I've heard some people like that... They say the same. Uh... } \\
\text { But, why do you think this way? Is it like that... }\end{array}$ \\
\hline
\end{tabular}

In most of the seven teletandem sessions of the partnership analyzed in this study, Daniel presents himself as a student who is very interested in learning about Brazil. This can be noticed early on, in the first of the seven teletandem sessions he had with Leticia. The first seven lines of Excerpt 3 show Daniel setting up the conversational context to discuss a theme of his interest - "Brazil as an emerging power in the world". As Daniel outlines his identity in his performance with words, as a student of International Relations (and interested in Latin America and Political Science), he sets up a positive and quite diplomatic tone, highlighting Brazil's strengths and "crucial moment of its history" (line 1). He wishes to find out from his Brazilian teletandem partner if Brazilians are aware of all of its power ("I do not know what the perception within Brazil is. What do you think?").

In the doing of teletandem intercultural communication", Daniel's identity performance and interest are local and have a historical context. $\mathrm{He}$ is a Latin American who emigrated from a Spanish-speaking Caribbean 
country as a child. Since then, he has been living and studying in the United States. No matter how far or close his life might have been to the community of his roots, both his life and education evolved within a country that is frequently engaged in wars. Particularly after the tragedy of September $11^{\text {th }}$ and for the sake of its own national security, the US has been concerned with how power transits among nations. Therefore, in line with Price (1999, p. 582), Daniel's subject positioning in the discursive engagement with his Brazilian teletandem partner is not deliberate. He is interpelated (in Butler's terms) by pre-existing local histories and sedimented discourses as a Latin American living in the US. A similar process happens with Leticia in line 8 of the above excerpt. Leticia's performance takes on the ideology of the emerging powerful country, but such performance is still interpelated by fixed, stable, and stereotypical images of the illiterate Brazilian, as if countries around the world would not have the same problems that Brazil must face (high illiteracy rates, low quality basic education, criminality, and social injustice).

In line with Pennycook (2004), who offers Butler's development of the notion of performativity as an alternative way to think about language, Excerpt 3 also shows that Daniel's and Leticia's identities are "interpelated into being" (p. 8) right in the doing of the intercultural discourse of teletandem.

In Excerpt 4 of their second teletandem interaction, Daniel and Leticia discuss the crisis of the real estate business in the United States over the past few years.

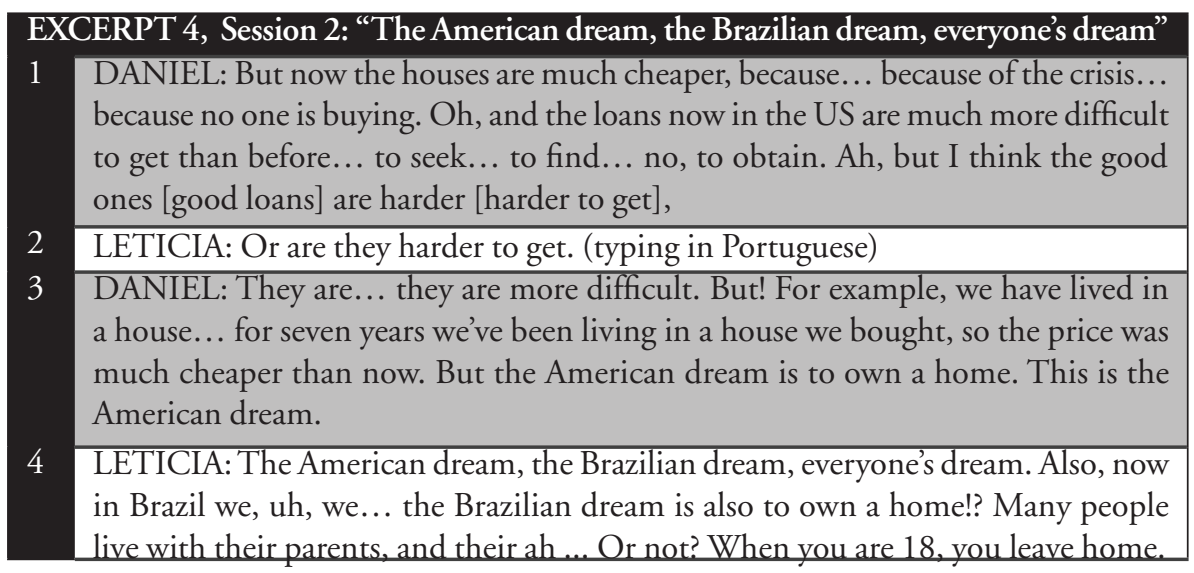

Here, an instance of teletandem intercultural discourse appears when partners discuss their similarities rather than their differences, in turn showing a transcultural aspect of teletandem conversation that transcends 
national or ethnic borders and produces a similar or hybrid category - the world citizen - as Leticia suggests in line 4 ("The American dream, the Brazilian dream, everyone's dream.”). In this case, the teletandem partners share their common social practices and difficulties, such as the dream house and the difficulties of getting a house loan. Daniel presents people's normative desire of owning a house as "The American Dream" (line 3). However, Leticia deconstructs Daniel's pre-existing and sedimented concept of "The American Dream" by saying that owning a house is not only an American dream, but also a dream for Brazilians and everyone's dream (line 4). If we consider Leticia's position in the conversation as a representative of Brazilians and Brazil, she recognizes such a dream as part of the Brazilian identity that she performs.

Excerpt 5 below is a continuation of Excerpt 4, still in their second session of teletandem. The theme about having one's own home develops into a discussion about different and similar social practices of children leaving their parents' home in Brazil and in the US.

\section{EXCERPT 5, Session 2: "Latin culture: My home, my mother, my father"}

1 LETICIA: The American dream, the Brazilian dream, everyone's dream. Also, now in Brazil we ah, we... the Brazilian dream is also to own a home. Many people live with their parents, and their ah ... Or not? When you are 18, you leave home. Previously, people left home earlier. They used to go straight to work, straight to college. Today, I think young people are getting too sluggish.

2 DANIEL: What?

3 LETICIA: They are too lazy, too sluggish. Kids are leaving home later today.

4 DANIEL: Later. Very sluggish, very loose. All right. Why? Economic situation?

5 LETICIA: No. Because it is a way of postponing adolescence, maturity. Instead of becoming mature sooner, of going to work, of going to school, they get into a crisis of existence. "Oh! What, am I going to do?" Such a crisis lasts until they turn 20, 21,25 . There are people who leave home in their 30s. "What am I gonna do, you know?” It's an existential crisis. So, today, maturity generally comes later.

6 DANIEL: Here in the US is not like that. Here, at 18, Mom and Dad say you have to go enter a university, goodbye, goodbye and, then, it's your life. This happens in the American culture. In the Latin culture, my home, my mother, my father, pish! They do not want me, me, me to leave home.

7 LETICIA: I believe this is Latin American, Brazilian. We are warm, with a little of, how can I put it ... Our parents wish to keep their children under their little wings, you know. That's how it works. 
As they share their views of social practices in North America and Brazil, of children leaving their parents' homes to work or to study, both partners perform the identities of their countries. Leticia justifies the problem of young Brazilians not wanting to leave home from an existentialist point of view - a "crisis of existence" (line 5). She gives no critical thoughts about the genealogy for such a "crisis of existence." For example, an alternative explanation could be that the Brazilian public (and, to a certain extent, private) educational system does very little to challenge its students academically and to promote contexts in which to reflect on their social contexts and relationships critically. Daniel, in turn, objectively explains the situation as an American normative practice of leaving home for university means leaving home for an economic and independent life from the parents (line 6). So far, these partners are still separate, as a Brazilian and an American.

However, at the end of line 6, Daniel mentions the normativity of a sedimented identity ascribed (as he himself suggests) to children of Latin families: "In the Latin culture, my home, my mother, my father, pish! They do not want me, me, me to leave home." (line 6). Such Latin identity is consolidated by Leticia's stereotyped and sedimented ideas of Latin people being warm and Latin parents' being protective: "Our parents wish to keep their children under their little wings, you know, that's how it works." (line 7). However, language use does not necessarily mirror the social, as suggested by Pennycook (2004, p. 13). In the above excerpt, both partners appropriate the commonly shared uncritical category of Latin parents being warm. However, both Daniel and Leticia have left home to study at a university. In Excerpt 5, identity cannot be conceived only as being a pre-given construct. The conversation in this excerpt can also be interpreted as a critical instance of the partners' conversation about Latin parents' overprotectiveness toward their children as a way of maintaining financial and personal control over their children's lives, under their own roof ("Our parents wish to keep their children under their little wings, you know..." - line 8).

Pennycook (2004, p.13) is right when he says that performativity "provides a way of thinking about relationships between language and identity that emphasize the productive force of language in constituting identity rather than identity being a pre-given construct that is reflected in language use." As he argues, "we perform identities with words, rather than reflect identities in language. We also perform languages with words. Identities are formed in the linguistic performance rather than pre-given" (Pennycook, 2007, p. 73-76). 
As he develops his identity performance with Leticia, Daniel mentions his upbringing to mark the difference between his Latin origin and that of others: "In the Latin culture, my home, my mother, my father, pish! They do not want me, me, me to leave home." (line 7). His performance (through words) appears to show him as being interpelated by a sedimented concept of a regulatory Latin cultural practice. It confirms Butler's thoughts about the fabrication of identities: "Identities are a product of our ongoing performances of acts that are largely pre-scribed (...) within highly rigid regulatory frames" (Butler, 1999, p. 70).

Hence, these principles of Performativity Theory can have serious ramifications when they are considered within the pedagogical context of foreign language teaching/learning and of intercultural communication through teletandem sessions. It is not difficult to see teletandem partners choosing easier and uncritical solutions to solve problems that may be much more profound. These are situations in which teletandem interactions may function to sediment pre-given concepts about identities and social practices through partners' intercultural discourse of difference. That may well be the case if they are not appropriately and critically mediated by a well-informed language teacher who is willing to put such sedimented concepts into check and who is aware of the force of language in constituting identity.

As the number of teletandem sessions progressed, the themes discussed by Daniel and Leticia became more complex and dealt with deeper social issues over the eight weeks of interaction (Brazilian favelas/slums, sexuality in Brazil, etc.). The instructors set up eight teletandem sessions, one per week, for a period of eight weeks. Excerpt 6 below was taken from the seventh session. It is important to mention that Daniel was planning to participate in a six-month Study Abroad Program in Rio in the following semester. Therefore, bringing stereotypical themes about Brazil into the online conversation with his partner, such as Rio, favelas (slums), Carnival, Brazilian sexuality, beauty and sensuality of Brazilian women, and the like into the conversation was very important to confirm or refute sedimented concepts about Brazil. Having relatively accurate information regarding Brazilian social challenges and wishing to obtain local information straight from "a native" of the country (as opposed to information conveyed through the American media), in Excerpt 6, Daniel's question is quite straightforward: Are Brazilians interested in helping the people of the slums? 


\begin{tabular}{|c|c|}
\hline & $\begin{array}{l}\text { CERPT 6, Session 7: "We are willing to help them. We become Brazilian." } \\
\text { DANIEL: Okay. It is the largest, of of South America [the Rocinha Favela, in Rio]. } \\
\text { No, the pregunta, the question is: Are Brazilians interested in helping the people } \\
\text { of the slums? }\end{array}$ \\
\hline 2 & LETICIA: Look / \\
\hline 3 & DANIEL: There is/ \\
\hline 4 & LETICIA: I can't/ \\
\hline 5 & DANIEL: Sorry, is there/ \\
\hline 6 & LETICIA: I can't tell you exactly/ \\
\hline 7 & DANIEL: $\ldots$ is there this social concern? \\
\hline 8 & $\begin{array}{l}\text { LETICIA: Yes. Nobody wants Brazil to have favelas, you know, especially in Rio } \\
\text { de Janeiro, a super target city for visiting and tourism. And Brazilians are very } \\
\text { charitable people, a people that care about this, but I don't know. I think so... I } \\
\text { think Brazil is concerned about helping to end slums. I mean, there's also this part, } \\
\text { I mean, we are... we are willing to help finishing it and such, but the thing is that } \\
\text { Brazilians are also a bit... we're very nervous, angry. }\end{array}$ \\
\hline 9 & DANIEL: You are very what? \\
\hline 10 & $\begin{array}{l}\text { LETICIA: Nervous, angry at violence. So, people think about the slums and wish } \\
\text { them to be destroyed, they want the police to come and drop a bomb in the slum. } \\
\text { But we are willing to help them. We become Brazilian. Did you see the movie "Elite } \\
\text { Squad: The enemy within"s? }\end{array}$ \\
\hline 11 & $\begin{array}{l}\text { DANIEL: Yes, I watched the plot summary you sent me to read, but not the movie, } \\
\text { such as...I saw "Elite Squad"6. }\end{array}$ \\
\hline 12 & $\begin{array}{l}\text { LETICIA: When you watch the, the, the "Elite Squad: The enemy within" you will } \\
\text { understand this, you will see that this is so, Brazilians wants to help in the slums, } \\
\text { just like the first movie, you saw it? Elite Squad was about a group of students } \\
\text { who had an } \mathrm{NGO}^{7} \text { and will / there are many people who do this kind of work } \\
\text { here. NGOs that help any poor neighborhood, and in Rio de Janeiro, in this case, } \\
\text { they help slums. Here, in São Paulo, you can find them in my town, everywhere, } \\
\text { you know, places that help, NGOs that help poor neighborhoods, people living } \\
\text { in tents, etc... But, in the case of Rio de Janeiro, because people are... they get } \\
\text { nervous because of the drug trafficking violence, then they want, they think that } \\
\text { by exterminating, if they drop a bomb in the slum and kill everybody they will } \\
\text { solve the problem (laughter). So it's kind of hard to just... this question ... It is not } \\
\text { everyone who has compassion with the slums, vou understand? }\end{array}$ \\
\hline
\end{tabular}

${ }^{5}$ The movie Elite Squad 2: The enemy within (2010) is a continuation of the movie Elite Squad (2007), both directed by José Padilha in 2010.. See movie review at http:// movies.nytimes.com/2011/11/11/movies/elite-squad-the-enemy-within-from-brazilreview.html?_r=0.

${ }^{6}$ See film plot summary at http://www.guardian.co.uk/film/2008/aug/10/worldcinema. thriller.

${ }^{7} \mathrm{NGO}$ - Non-Governmental Organization. 


13 DANIEL: Right.
$14 \begin{aligned} & \text { LETICIA: Not everyone thinks we must help them. There are many people who think } \\ & \text { you have to blow up the slums and stop the evil at its root. But it's not like that, you } \\ & \text { know? }\end{aligned}$
15 DANIEL: But if there is no alternative, then you can't do it.
16 LETICIA: Yes.
17 DANIEL: C
18 LETICIA: Right, exactly.
19 DANIEL: You must live on one side.
$\begin{aligned} & \text { LETICIA: The police want to come and kill everybody, attacking everything. } \\ & \text { But, because there are many good people living there, one cannot tell who's who. } \\ & \text { Because they hide. That's exactly what I told you, they hide what's going on in the } \\ & \text { slums, because drug dealers are the ones who help the slums. So, it's impossible. The } \\ & \text { police get there and do not know which family is a good family. Because everybody } \\ & \text { says... everyone has the same discourse. "What, what's happening?", "I don't know, } \\ & \text { I don't say anything, I'm afraid." Everyone says: "I'm afraid of talking." Then the } \\ & \text { police interrogate someone, they only interrogate by beating them, only if beating } \\ & \text { them, you know, to make the guys talk about what, about what's going on, and } \\ & \text { nobody says anything. }\end{aligned}$

In line 1, Leticia tries to perform a least possible negative view of the favelas by telling Daniel that the Rocinha favela, in Rio, in one of the biggest in Brazil. Daniel corrects the information immediately by saying "It's the biggest in Latin America!" Leticia has no option, but to confirm he is right. This correction of information, as well as other parts of the conversation preceding Excerpt 6, showed an American student who is quite well informed about Brazil and with a profound interest in confirming information he has previously obtained from a native-speaker (his teletandem partner), or probably from courses he took, or even from magazines.

Daniel's question "Are Brazilians interested in helping the people of the slums?" is followed by a sequence of overlapping turn-takings (lines 2 to 6), when Leticia attempts to organize an answer to Daniel's complex question, until he rephrases his question in line $7:$ : $\ldots$ is there this social concern [of helping people of the slums]".

What follows in lines $8,10,12,14$, and 20 are Leticia's performance of multifaceted Brazilian identities, as she attempts to answer Daniel's question (in Butler's terms, Leticia's "doing with words"): Brazilians are performed as being, at the same time, (a) helpful, (b) charitable and compassionate, (c) nervous, and (d) angry and violent in relation to the situation of people in the favelas. This performance of Brazilian identities through Leticia's 
linguistic behavior corroborates with what Harrisi et al. (2012, p. 540) explains as "momentary playing with possibilities, with trying out certain identity meanings in the doing." Such a "playing with possibilities" does not preclude possible contradictory attempts on the part of Leticia to identify Brazilians to her American partner: "(...) people think about the slums and wish them to be destroyed, they want the police to come and drop a bomb in the slum. But, we are willing to help them. We become Brazilian" (line 10).

The deictics "people" and "they" are different from the deictic "we", in the above quote. "People" and "they" wish to destroy and drop bombs in the favelas, whereas "we", the Brazilians, wish to help them (the people of the favelas). However, "people" and "they" refer to the people of Brazil just as "we" and "Brazilians" do. Leticia's effort to perform a positive identity of Brazilians to her American partner becomes explicit in her last sentence: "We become Brazilian."

In Leticia’s performance, help comes associated with almost religious charity and compassion, instead of acts of social work or public policy: "And Brazilians are very charitable people, a people that care about this, but I don't know" (line 8). However, the works of NGOs are mentioned in order to sweeten the pill and to perform a more positive view of Brazil (and of her own national identity to her American partner). Letícia further explains that nervousness comes from not knowing how to proceed in relation to the social situation,.

Daniel summarizes Leticia's lengthy attempts to explain people's lives in the slums of Rio de Janeiro. Based on Leticia's performance, in lines 15 ("But, if there is no alternative, then one can't do it.") and 19 ("You must live on one side."), Daniel concludes that people living in the slums of Rio must take one side - the police's or the drug dealers': favela inhabitants are presented by Leticia as survivors of social anger, violence, and injustice, as they live their lives between the institutional power of the police and the contesting (though not less violent or oppressive) power of the drug dealers. Daniel's triggering question about whether or not there is social concern in helping the people of the slums carries a stable cultural identification agenda of Brazilians.

\section{Results and discussion}

Unlike other sorts of online conversation, the analysed data shows that teletandem conversation cannot be exclusively considered "fun talk" for 
practicing and learning foreign languages (of course, without depreciating the positive, possibly effective, and useful points that "fun talk" can offer language learners and teachers). Rather, it is a virtual and active locus of negotiation of identities (p. 8). Thus, there is much more to that than a simple friendly online chat. The data presented here show evidence of a context that is replete with opportunities for the expression of subjectivities or ideologies, most of which might go unnoticed if not appropriately dealt with by the teachers who are responsible for the session mediations. That being said, the results of this analysis pose serious issues regarding the educational background, the previous intercultural experiences, and the ideological positions of these teacher-mediators (as of any other educator responsible for a classroom).

\section{How do teletandem practitioners perform their identities du- ring the intercultural interaction of teletandem?}

The data analysis of this study consisted of reflections on the transcribed data. These reflections were grounded on readings about Performativity Theory (BUTLER,1999; PENNYCOOK, 2012, 2004;, MILLER, 2012). The study has attempted to show how the intercultural discourse of teletandem set up a context for performing notions or aspects of Brazil, of Brazilians, and of what Brazilians do.

The present study served to highlight explicit and implicit performances about Brazil in Daniel's and Leticia's teletandem interaction. Explicit performances, here, can be defined as instances of the conversation in which partners use the word Brazil or Brazilian, for example, as compared to implicit performances in which themes about Brazil are indirectly inferred from the Brazilian partner's voice or turn.

Corroborating with Pennycook's (2004, p. 1) findings, identities in the online teletandem collaboration of this study can be seen not as pre-given, but as ascribed to people and as recursive and socially ongoing performances. In these performances, language plays a central role in the "fabrication" or "invention" (Woodward, 2000, p. 219) of the foreign language students' national identities. As pointed out by Kramsch \& Uryo (2014), Daniel and Leticia can be considered as "active producers and speakers of discourses [about national identities] that are beyond their control” (p. 219).

Another key point to elucidate performances of national identities in the intercultural communication through teletandem is what Butler 
(1999) calls the processes of sedimentation, in the case of this paper, within the Brazilian student's presentation of Brazil, of Brazilians, and of what Brazilians do. As Leticia performatively presents Brazil to her American partner during the teletandem conversation, she performs what she believes to be her national identity (if that can be said to exist). Leticia tries to explain the cultural practices of her country. As she does this, what can be seen as performatively realized by Leticia during her teletandem interaction is an ideological perspective of Brazil and its people. Such a perspective is presented in the form of a unitary autonomous system comprised of meanings gathered within the social and sedimented by repetition.

Many other instances could have been examined within this communication; however, the particular aspect of teletandem intercultural communication was chosen as the main focus due mainly to limitations of space within this article.

\section{What gains can foreign language pedagogy have once online interactions in teletandem are considered from the perspecti- ve of performativity?}

The results of the analysis presented in this paper can inform teachers and the teaching of foreign languages through telecollaboration. Teletandem sessions are frequently followed by mediation sessions. During these sessions, the language instructor sets the classroom context for students' discussions on the interactive, linguistic, and cultural aspects of what they experienced during teletandem. If the teacher is not critically well informed about such issues, the mediation session may not transcend the level of mere reports of experience, in turn perpetuating stereotypes and sedimented conceptions of self and other. Having students simply interact with people and languages from other countries is not enough. Teachers' use of teletandem sessions as a pedagogical strategy, therefore, must be done carefully, and teacher development to deal with teletandem must be carefully and attentively planned, especially with the teacher colleague abroad.

From a pedagogical point of view, students cannot simply be left to communicate online through teletandem for their own sake, particularly when dealing with teenagers' teletandem sessions, for example. Therefore, the online context of teletandem for transcultural communication, per se, does not educate students towards global citizenship. Rather, it is the ways that instructors use this online learning context (as when they use any other 
teaching approach or technique) that may promote the critical teaching and learning of foreign languages as well as the critical appreciation of identity and difference. Understanding how these notions are performed is important not only to students, but also to language instructors. They must deal with such issues in their professional development, as they increasingly adopt technologies for transcultural and transcontinental interactions in their language classes. For example, every nation has its "national wound(s)", which are frequently connected to feelings of shame, guilt, or revolt on the part of its peoples. Discussing such themes is like putting one's finger in the other's wound, and it poses challenges to transcultural communication, particularly at times when its costs become ever-increasingly lower due to the development of new technologies.

The ways of using teletandem for transcultural and transcontinental communication, therefore, include, amongst other aspects, the awareness of power issues during this kind of interaction and of the performative processes of identities. These are aspects to be carefully thought out and attended to during teachers' teletandem mediation sessions, as students report and share their stories of online interactions with their partners abroad.

Finally, bearing in mind such online-based intercultural discourse studies from critical perspectives, we, the teachers, may be able to articulate pedagogical and educational strategies to broaden users' views of technology, to revisit frequently misguided and essentialist understandings of world social realities, and to open pathways to foreign language education and foreign language teacher development for intercultural citizenship (Byram, $2011,2008)$. In addition, a deeper understanding of intercultural discourses can also work towards avoiding the current world tendency to perpetuate stereotypes (Fant, 2012) and discourses about culture that "serve to obscure inequality between and within groups" (Piller, 2012, p. 03). Mediation sessions conducted by the instructors may also promote transformative, diverse, and dynamic (as opposed to static) understandings of culture.

\section{Final remarks}

A few limitations of this qualitative, interpretive, and exploratory case study must be considered here. First, seven teletandem sessions of a single partnership between an American male and a Brazilian female were used. Therefore, there are also clear limitations of the study in terms of nationality, gender combination, pairing, and sampling (only two out of 
one hundred students were chosen). Second, due to space limitation, this study worked with the data in Portuguese, with a focus on Brazil. Inspecting the data in English, with a focus on the US, could have confirmed (or even disconfirmed) many of the processes and interpretations presented in my analysis. Third, the particular teletandem partnership was chosen for analysis, as it showed a revealing, rich, and interesting set of circumstances.

Certainly, all of these aspects affected the study's final results and its potential and scope to render generalizations, even though the latter was neither my purpose, nor even my interest here. My intention in this study was to introduce Performativity Theory as a productive perspective from which to consider foreign language students' processes of subjectivation by analyzing the intercultural discourse of a set of teletandem interactions. I then tried to outline possible pedagogical implications of adopting this theory in practices of foreign language teaching and learning that use teletandem as mode of online intercultural telecollaboration. The results of this study can serve to support subsequent studies and reflections of teachers who are in charge of teletandem mediation sessions or who wish to use teletandem in their classes.

\section{References}

BENEDETTI, A.M., CONSOLO, D.A., VIEIRA-ABRAHÃO, M.H. Pesquisas em Ensino e Aprendizagem no Teletandem Brasil: Linguas estrangeiras para todos. Campinas: Pontes Editores, 2010.

BRAMMERTS, H. Autonomous language learning in tandem: The development of a concept. In: LEWIS, T.; WALKER, L. (Eds.) Autonomous Language Learning in Tandem. Sheffield: Academic Electronic Publications, 2003. p. 27-36.

$\mathrm{BROCCO}, \mathrm{A}$. A gramática em contexto de teletandem e em livros didáticos de português como lingua estrangeira (Masters Thesis in Linguistics).São Josédo Rio Preto: Institutode Biociências, Letrase Ciências Exatas/UniversidadeEstadual Paulista, 2009. Available at: http:// www.teletandembrasil.org/site/docs/BROCODISS.pdf. Retrieved February 18, 2014.

BUTLER, J. Gender Trouble: Feminism and the subversion of identity. New York: Routledge Press, 1999.

BYRAM, M. From Foreign Language Education to Education for Intercultural Citizenship. Clevedon: Multilingual Matters, 2008.

BYRAM, M. Intercultural citizenship from an internationalist perspective. Journal of the NUS Teaching Academy, Vol. 1, issue 1, 2011, p. 10-20. 
CANAGARAJAH, A.S. Postmodernism and intercultural discourse: World Englishes. In: PAULSTON, C.B.; KIESLING, S.F.; RANGEL, E.S. (Eds.). The Handbook of Intercultural Discourse and Communication. West-Sussex: WileyBlackwell Publishing Ltd, 2012. p. 109-132.

FANT, L. "Those venezuelans are so easy-going!" National stereotypes and selfrepresenations in discourse about the Other. In: PAULSTON, C.B.; KIESLING, S.F.; RANGEL, E.S. (Eds.). The Handbook of Intercultural Discourse and Communication. West-Sussex: Wiley-Blackwell Publishing Ltd, 2012. p. 271-290.

GÓIS, E.R. As diferenças culturais no teletandem. Available at: http://www. teletandembrasil.org/site/docs/GOIS.pdf. Retrieved February 18, 2014.

GUEST, M. A critical 'checkbook' for culture teaching and learning. ELT Journal, Vol. 56, issue 2, 2002, p. 154-161.

HARISSI, M.; OTSUJI, E.; PENNYCOOK, A. The performative fixing and unfixing of subjectivities. Applied Linguistics, Vol. 33, issue 5, 2012, p. 524-543.

KRAMSCH, C.; URYU, M. Intercultural contact, hybridity, and third space. In: JACKSON, J. (Ed.) The Routledge Handbook of Language and Intercultural Communication. New York: Routledge, 2014, p. 211-225.

KUBOTA, R. Critical approaches to intercultural discourse and communication. In: PAULSTON, C.B.; KIESLING, S.F.; RANGEL, E.S. (Eds.). The Handbook of Intercultural Discourse and Communication. West-Sussex: Wiley-Blackwell Publishing Ltd, 2012. p. 89-109.

KULICK, D. No. Language \& Communication, Vol. 23, issue 2, 2003, p. 139-151.

LEONE P. Leadership in multimodal computer-mediated second language communication for reciprocal learning. Journal of e-Learning and Knowledge Society, Vol. 8, issue 3, p. 55-66, 2012, p. 55-66.

LEONE, P. Comunicazione mediata dal computer e apprendimento linguistico: Gli incontri teletandem. Studi di Glottodidattica, Vol. 1, issue 1, 2009, p. 90-106. LEVY, M. Culture, culture learning and new technologies: Towards a pedagogical framework. Language Learning \& Technology, Vol. 11, issue 2, 2007, p. 104-127.

MCILVENNY, P. Critical reflections on performativity and the 'un/doing' of gender and sexuality in talk. In: MCILVENNY, P. (Ed.). Talking gender and sexuality. Philadelphia: John Benjamins, 2002. p. 111-149.

MENDES, C.M. Crenças sobre a língua inglesa: $\mathrm{O}$ antiamericanismo e sua relação como o processo de ensino-aprendizagem de professores em formação (Masters Thesis in Linguistics). São José do Rio Preto: Instituto de Biociências, Letras e Ciências Exatas / UniversidadeEstadual Paulista, 2009. Available at: http://www.teletandembrasil.org/site/ docs/MENDES_CM.pdf. Retrieved February 18, 2014. 
MILLER, E.R. Performativity theory and language learning: Sedimentating, appropriating, and constituting language and subjectivity. Linguistics and Education, Vol. 23, issue 1, 2012, p. 88-99.

MOITEIRO, M.N. Action research on teletandem: An analysis of virtual intercultural communication between students from Brazil and Germany. 2009. (Diplomarbeit in Linguistics). Johannes Gütemberg Universität, Meinz. Available at: http://www.teletandembrasil.org/site/docs/MOITEIRO.pdf. Retrieved February 18, 2014.

NVivo 10 Qualitative Analysis Software. Doncanster, Victoria, Australia: QSR International Available at: http://qsrinternational.com/products_nvivo.aspx. Retrieved February 18, 2014.

PENNYCOOK, A. Performativity and language studies. Critical Inquiry in Language Studies: An International Jornal, Vol. 1, issue 1, 2004, p. 1-19.

PILLER, I. Intercultural communication: An overview. In: PAULSTON, C.B.; KIESLING, S.F.; RANGEL, E.S. (Eds.). The Handbook of Intercultural Discourse and Communication. West-Sussex: Wiley-Blackwell Publishing Ltd, 2012. p. 2-18.

PRICE, S. Critical discourse analysis: Discourse acquisition and discourse practices. TESOL Quarterly, Vol. 33, issue 3, 1999. p. 581-595.

RODRIGUES, D.G. Os estereótipos e a construção da identidade linguísticocultural no processo de ensino/aprendizagem de língua estrangeira no contexto teletandem. FAPESP Scientific Initiative Grant Report, São José do Rio Preto, 2008. Available at: http://www.teletandembrasil.org/site/docs/RODRIGUES. pdf. Retrieved February 18, 2014.

SALOMÃO, A.C.B. On-line Collaborative Learning for In-service Teacher Education. Journal of Emerging Technologies in Web Intelligence, Vol. 3, issue 4, 2011a, p.268-272. Available at: http://ojs.academypublisher.com/index.php/jetwi/article/ view/5938. Retrieved February 18, 2014.

SALOMÃO, A.C.B. The education of teacher educators: perspectives of collaboration between undergraduate and graduate students in the Project Teletandem Brazil. Revista Brasileira de Linguistica Aplicada, Vol. 11, issue 3, , 2011b., p. 653-678. Available at: http://www.scielo.br/pdf/rbla/v11n3/04.pdf. Retrieved February 18, 2014.

SANTOS, G.R. Características da interação no contexto de aprendizagem in-andem. (Masters thesis in Linguistics) - São José do Rio Preto: Instituto de Biociências, Letras e Ciências Exatas / Universidade Estadual Paulista, 2008. Available at: HTTP://www.teletandembrasil.org/site/docs/DissertacaoGersonRossi. pdf. Retrieved February 18, 2014. 
SANTOS, G.R. O que acontece durante as interações de teletandem: Investigando os dados. In: TELLES, J.A. (Org.). Teletandem: Um contexto virtual, autônomo e colaborativo para aprendizagem de linguas estrangeiras no século XXI. Campinas: Pontes Editores, 2009. p. 121-146.

SHI, X. Critical pedagogy and intercultural communication: Creating discourses of diversity, equality, common goals and rational-moral motivation. Journal of Intercultural Studies, Vol. 22, issue 3, 2001, 279-93.

SWAIN, M.; LAPKIN, S. Interaction and Second Language Learning: Two Adolescent French Immersion Students Working Together. The Modern Language Journal, Vol. 82, issue 3, 1998, p. 320-337.

TELLES, J.A. Teletandem: Um contexto virtual, autônomo e colaborativo para aprendizagem de línguas estrangeiras no século XXI. Campinas: Pontes Editores, 2009. TELLES, J.A. Teletandem: Metamorfoses impostas pela tecnologia sobre o ensino de línguas estrangeiras. In: TELLES, J.A. (Org.). Teletandem: Um contexto virtual, autônomo e colaborativo para aprendizagem de línguas estrangeiras no século XXI. Campinas: Pontes Editores, 2009b. p. 61-72.

TELLES, J.A. Do we really need a webcam? The uses that foreign language students make out of webcam images during teletandem sessions. Letras \& Letras, Vol. 25, issue 2, 2009c, p. 65-79.

TELLES, J.A. Teletandem: Transculturality and identity in webcam interactions in foreign languages. In: Conference Proceedings, International Conference ICT for Language Learning 5th Edition, October, 20-21, 2012, Firenze: Libreria Universitaria. ISBN: 978-88-6292-309-5. Available at: http://conference.pixelonline.net/ICT4LL2012/common/download/Paper_pdf/321-IBT62-FP-TellesICT2012.pdf . Retrieved February 18, 2014.

TELLES, J.A.; FERREIRA, M.J. Teletandem: Possibilidades, dificuldades e abrangência de um projeto de comunicação online de PLE. Horizontes em Linguistica Aplicada, Vol. 9, issue 2, 2011, p. 79-104.

TELLES, J.A.; VASSALLO, M.L. Foreign language learning in-tandem: Teletandem as an alternative proposal in CALLT. The Especialist, Vol. 27, issue 2, 2006, p. 189-212.

TELLES, J.A.; VASSALLO, M.L. Teletandem: Uma proposta alternativa no ensino/aprendizagem assistidos por computadores. In: TELLES, J.A. (Org.). Teletandem: Um contexto virtual, autônomo e colaborativo para aprendizagem de linguas estrangeiras no século XXI. Campinas: Pontes Editores, 2009a. p. 41-60.

VASTERLING, V. Butler's sophisticated constructivism: A critical assessment. Hypatia, Vol. 14, issue 3, 1999. p. 17-38. 
VASSALLO, M.L.; TELLES, J.A. Aprendendo línguas estrangeiras in-tandem: Histórias de identidades. Revista Brasileira de Linguística Aplicada, Vol. 8, issue 3, 2008, p. 341-381.

WOODWARD, K. Identidade e diferença: Uma introdução teórica e conceitual. In: SILVA, T.T. da (Ed.) Identidade e Diferença: A perspectiva dos Estudos Culturais. Rio de Janeiro: Editora Vozes, 2000. p. 7-73.

Data de submissão: 19/02/2014. Data de aprovação: 29/07/2014. 